\title{
A Methodological Proposal for Quantifying Environmental Compensation Through the Spatial Analysis of Vulnerability Indicators
}

\author{
Fabio Enrique Torresan ${ }^{1} *$ and Reinaldo Lorandi ${ }^{2}$ \\ ${ }^{1}$ EMBRAPA Monitoramento por Satélite; torresan@cnpm.embrapa.br; Av. Soldado Passarinho, 303; Fazenda \\ Chapadão; 13070-115; Campinas - SP - Brazil. ${ }^{2}$ Universidade Federal de São Carlos (UFSCar); Dept. Engenharia \\ Civil; lorandi@power.ufscar.br;Via Washington Luís, km 235; C.P. 676; 13565-905; São Carlos - SP - Brazil
}

\begin{abstract}
The aim of this work was to propose a methodology for quantifying the environmental compensation through the spatial analysis of vulnerability indicators. A case study was applied for the analysis of sand extraction enterprises, in the region of Descalvado and Analândia, inland of São Paulo State, Brazil. Environmental vulnerability scores were attributed for the indicators related to erosion, hydrological resources and biodiversity loss. This methodological proposal allowed analyzing the local alternatives of certain enterprise with the objective of reducing impacts and at the same time reducing the costs of environmental compensation. The application of the methodology significantly reduced the subjectivity degree usually associated to the most of the methodologies of impact evaluation.
\end{abstract}

Key words: Environmental compensation, environmental impact assessment, GIS, landscape ecology, sand mining

\section{INTRODUCTION}

Nowadays, the mechanisms of environmental compensation have been objective of a wide debate in several segments of the Brazilian society, including the governmental sectors, entrepreneurs and the civil society. ${ }^{1}$ Environmental compensation is one of the most versatile and efficient government instruments for the permanent destination of the resources for the conservation units today. However, it is questioned to what extent certain environmental impacts or even the elimination of an ecosystem could be effectively "compensated." It should be emphasized that not everything can be compensated and the compensation, purely and simply, will never be able to be used in order to

\footnotetext{
*Author for correspondence
}

approve or accept all and any project, activity or enterprise.

The "environmental compensation" term treated in the present paper exclusively refers to the obligation of supporting the establishment and/or maintenance of the Protected Areas, applicable to the enterprises of significant environmental impact, in accordance with the Article 36 of Law 9985, of July $18^{\text {th }}, 2000$, also known as the Law of the National System of Conservation Units (SNUC). The law establishes that the environmental compensation will be obligatory for the enterprises of significant environmental impact and that the amount of the resources directed to the protected areas by the development enterprise must be at least $0.5 \%$ of the total project cost, being the percentage fixed by the environmental licensing authority, in accordance with the 
environmental impact degree caused by the enterprise.

The environmental licensing authority has been given the complex task of evaluating the "environmental impact degree caused by the enterprise" and defining the percentage of the environmental compensation. The issue established by the law is that not every enterprise should pay the same compensation value, because this value will depend on the "environmental impact degree" caused by the enterprise. The law established a minimum value of $0.50 \%$ of the total project cost, but it does not mention how one should quantify the "environmental impact degree", and doesn't even define the term "environmental impact degree".

According to Antunes et al. (2001), the assessment of the environmental impacts' significance always has a subjective dimension, resulting from the integration of the values, experiences and knowledge of the different actors involved in the evaluation. Although the subjectivity cannot be completely eliminated, the results of an evaluation can become more reliable if they are obtained through the application of a methodology previously defined, with clearly defined evaluation criteria, making use of the information generated in the environmental studies.

Any methodology of environmental impact assessment presupposes the analysis of a great amount of information, including the aspects of the socioeconomic, biotic and physical environment of certain area as well as the characteristics of the enterprise that is being evaluated. In this context, the application of spatial analysis tools as the geoprocessing, makes possible a greater agility, rapidness and precision in the information analysis.

Having in mind the spatial nature of many environmental impacts, Geographical Information Systems (GIS) may have a wide application in every step of the impact assessment process, acting as an integrating tool for the totality of the process, from the generation, storage, and visualization of the thematic information concerning the vulnerability of the affected resources, up to the prevision of impacts and at last their evaluation as support for the decision making process (Antunes et al. 1996).

This work had the main objective of proposing methodological procedures for the analysis of the environmental impact degree and respective compensation calculation through the application of geoprocessing tools.

\section{MATERIALS AND METHODS}

The proposed method originated from the presupposition that the relevance of environmental impacts was mainly associated to the vulnerability and susceptibility of the environmental components of the site that an enterprise would settle. The higher this vulnerability, greater is this vulnerability, the higher would be the environmental impact degree, and consequently, the compensation values would be higher.

\section{Study area}

The study was applied for the analysis of sand extraction enterprises in the region of Descalvado and Analândia, inland of São Paulo State, Brazil. The study area is located between the latitudinal parallels of $21^{\circ} 45^{\prime} \mathrm{S}$ and $22^{\circ} 15^{\prime} \mathrm{S}$ and the longitudinal parallels of $47^{\circ} 30^{\prime} \mathrm{W}$ and $47^{\circ} 45^{\prime} \mathrm{W}$. This region has stood out for its great potential of mineral exploitation of sand deposits and also stands out for its great environmental fragility represented by the presence of remainders of natural savanna vegetation and semidecidual seasonal forest, in addition to testimonial relieves ("cuestas"). These remainders suffer a great pressure of substitution for other anthrop activities such as the agricultural occupation and even the expansion of mineral exploitation activities.

\section{Methodology}

The main tool for the methodology application was the use of Geographical Information Systems (GIS), specifically IDRISI 32 (Clark University). The main diagnosis of the study area was through the production of cartographic documents, by information about the relief, pedology, geology, hydrograph, use and occupation of the soil and remainders of the native vegetation.

The Base Map was elaborated from the digitization of the information contained in the cartographic base of the study area, composed by the articulation of Descalvado (Brazil-IBGE, 1971a) and Corumbataí (Brazil-IBGE, 1971b) base maps. Primary and derived data were related to hydrographic, hypsometric and slope maps of the study area. The slope map was produced from a Digital Elevation Model (DEM) associated to the altimetry, elaborated in IDRISI 32, from the elevation isolines that were previously digitized, resulting in a raster image composed by 716 columns and 1000 rows, with a spatial resolution of 30 meters. The Map of Surface Geological 
Formations was produced from the compilation of the Geological Maps of Descalvado (São Paulo-IG 1984) and Corumbataí (São Paulo-IG 1984b).

The characterization and environmental diagnosis of the soils of the study area were accomplished from the compilation of the semi detailed pedological map of the Descalvado (Oliveira et al. 1982) and São Carlos (Oliveira et al. 1981), including the study area in question. The mapping of the land use and cover was accomplished through the interpretation of remote sensing images of the LANDSAT 7 satellite, ETM+ (Enhanced Thematic Mapper Plus), of April 27 ${ }^{\text {th }}$, 2002. The supervised classification method was used, where the user developed spectral signatures of the known land use categories and then the software attributed each "pixel" of the image category to which the signature was more similar (Eastman 1997). The classifying algorithm of the maximum likelihood was used (MAXLIKE), where the distribution of the reflectance values in a training site was described by a function of the probability of the densities, developed with base in the statistics of Bayes.

Accomplished through the geoprocessing, through the fuzzy logic modeling, the environmental vulnerability scores were attributed for the several components of the diagnosis from a standardized quantitative scale. Here, the term "environmental vulnerability index" was adopted as that defined by Bojórquez-Tapia et al. (2002) as the "susceptibility of an ecological component to the effects of determined activity of the project." The scale of the Environmental Vulnerability Indexes ranged from 0 to 1 , where zero corresponded to the minimum environmental impact degree $(\mathrm{EVI}=$ 0 ID) and 1 corresponded to the maximum environmental impact degree (EVI $=1 \mathrm{ID})$. The acronym "ID" corresponded to the environmental impact degree unit of measure.

Before determining the environmental vulnerability indexes, the identification of the impacts associated to the activity in question, in this case, the sand mining, is required.

\section{RESULTS AND DISCUSSION}

\section{Environmental diagnosis of the study area}

From the Numeric Model of the Terrain (NMT) elaborated from the level curves, it was observed that the altimetric variations found in the study area was located between the minimum of $580 \mathrm{~m}$ and maximum of $1040 \mathrm{~m}$, with a total unevenness of $460 \mathrm{~m}$ and an average of $781 \mathrm{~m}$. The areas of higher altitude were on the top of the relieves in form of "cuestas", as the Serrote do Descalvado, the Serra do Cuscuzeiro and the Serra do Atalaia. The areas of lower altitude happen in the low lands of the Pântano stream, the Bonito River and the Corumbataí River. Most of the area $(61 \%)$ included altitudes between 700 and $820 \mathrm{~m}$ and the extreme altitudes (between 580 and $620 \mathrm{~m}$ and superior to $980 \mathrm{~m}$ ) were limited to $3 \%$ of the area. The Slope Map indicated the predominance $(28 \%$ of the study area) of declivities between 5 and $10 \%$, followed by the classes of softer declivities (between 0 and 5\%). The classes of declivity more accentuated (superior to $30 \%$ ) occupied $5 \%$ of the study area and were located predominantly in the scarps of the relieves in form of "cuestas" (Serra do Cuscuzeiro, Serra do Atalaia, and Serrote de Descalvado).

By analyzing the results from the Land Use Map, it was observed that the pastures were the kind of predominant use in the study area, including an area of 22134 ha, which represented $35 \%$ of the total area. It should be highlighted that great part of the areas classified as "exposed soil" actually concerned the areas in which at the time of the image registration by the satellite were being prepared for the planting of the annual cultures, predominantly sugarcane. Thus, the areas with annual cultures represented more than $14 \%$ of the study area. The urban areas encompassed only 103 ha of the study area, revealing the low urbanization degree. The areas of sand mining in operation corresponded to more than the double of the urban areas, about 253 ha.

The remainders of savannah vegetation, ciliary vegetation and semidecidual seasonal forest revealed a quite representative value of $26 \%$ of the study area (16839 ha), highlighting the importance in terms of the biodiversity of the selected area, which implicated the need of conservation.

The results revealed the occurrence of 1543 fragments in the study area (see Table 1). The average area of the fragments was 10.91 ha and the largest fragment possesses area of 2125 ha, located to the south of the urban area of Analândia and nearby the Serra do Atalaia. Most of the fragments (976) possessed the area smaller than 1 ha, revealing the high pressure and fragmentation degree on the savannah remainders and seasonal forest. 
Table 1 - Area of the natural vegetation fragments

\begin{tabular}{lcrc}
\hline Area classes & Number of fragments & Area (ha) & $\%$ \\
\hline$>2000$ ha & 1 & 2125.71 & 12.62 \\
$1000-2000$ ha & 2 & 2614.23 & 15.52 \\
$500-1000$ ha & 4 & 3200.59 & 19.01 \\
$300-500$ ha & 2 & 720.04 & 4.28 \\
$200-300$ ha & 7 & 1576.02 & 9.36 \\
$100-200$ ha & 10 & 1538.45 & 9.14 \\
$50-100$ ha & 18 & 1224.06 & 7.27 \\
$30-50$ ha & 15 & 579.78 & 3.44 \\
$20-30$ ha & 29 & 714.36 & 4.24 \\
$10-20$ ha & 54 & 798.77 & 4.74 \\
$5-10$ ha & 75 & 543.48 & 3.23 \\
$4-5$ ha & 46 & 206.20 & 1.22 \\
$3-4$ ha & 70 & 242.96 & 1.44 \\
$2-3$ ha & 87 & 216.74 & 1.29 \\
$1-2$ ha & 147 & 211.34 & 1.25 \\
$<1$ ha & 976 & 327.18 & 1.94 \\
\hline TOTAL & 1543 & 16839.91 & 100.00 \\
\hline
\end{tabular}

\section{EVI related to erosion (EVI EROSION)}

This index reflects the vulnerability to the unchainment of impacts as the intensification of erosive processes and consequently the intensification of the sedimentation of rivers. It is composed by the average of the vulnerability indexes relative to the slope (EVI SLOPE), geology (EVI GEO) and pedology (EVI PEDO), which will be described hereinafter. In this way, EVI EROSION (Figure 1) is described by the following function:

EVI EROSION $=\frac{\text { EVI SLOPE + EVI GEO + EVI PEDO }}{3}$

The EVI related to slope (EVI SLOPE) is considered that the greater the slope of certain area, the greater its vulnerability will be for the unchainment of these impacts, resulting in a greater degree of environmental impact. This way, the slope of $0 \%$ correspond to an environmental impact degree of 0 ID (minimum impact degree) and the slopes equal or superior to $45 \%$ correspond to an environmental impact degree of 1 ID (maximum impact degree), where the influences of the slope on the unchainment of erosive processes will be maximized.

The EVI related to geology (EVI GEO) was produced from the information obtained in the geological map, it was adopted the attribution of vulnerability scores for the intensification of erosive processes (Table 3) according to the methodology proposed by Crepani et al. (1998) and modified by Souza (1998), from information relating to the cohesion degree of the main minerals that compose the study area geological formations. The proposed scores ranges from 1 to 3 , and seeing that the closer to 3 , the greater the vulnerability will be for the unchainment of erosive processes and consequently the greater its environmental impact degree will be.

The EVI related to pedology (EVI PEDO) was produced from the information obtained in the pedological map, it was adopted the attribution of vulnerability scores for the intensification of erosive processes (Table 2) according to the methodology proposed by Crepani et al. (1998) and modified by Souza (1998). The proposed scores ranges from 1 to 3 , and seeing that the closer to 3 , the greater the vulnerability will be for the unchainment of erosive processes and consequently the greater environmental impact degree will be.

\section{EVI related to impacts on the hydrological resources (EVI HYDRO)}

This index reflects the vulnerability to impacts on the hydrological resources (Figure 2), as spilling of pollutant (accidental or not), carrying of solid residues, among others. The information was obtained from the documentation map, where the rivers of the study area were selected, by generating an image with all of the rivers and bodies of water. The DISTANCE module of 
IDRISI was applied, by generating a new image representing the distance between the rivers. It was considered with minimum impact degree $(\mathrm{EVI}=0$ ID) areas where the distance up to the closest river was longer than 1000 meters. The maximum impact degree (EVI=1 ID) corresponds to areas where this distance approached zero.

Table 2 - Scores for the EVI related to pedology.

\begin{tabular}{lc}
\hline Pedology & Score \\
\hline Red-Yellow Latosol (Haplorthox) & 1.00 \\
Dusky-Red Latosol (Typic Eutrorthox) & 1.00 \\
Dark-Red Latosol (Typic Haplorthox) & 1.00 \\
Sandy Soils (Typic Quartipsammentic) & 3.00 \\
Lithosols (Typic and Lithic Udorthent) & 3.00 \\
Red-Yellow Podzolic (Typic Paleudult) & 2.00 \\
Hydromorphic soils (Typic Albaquults) & 3.00 \\
"Terra Roxa Estruturada" (Rhodic Paleudalf) & 2.00 \\
\hline
\end{tabular}

EVI related to biodiversity loss and suppression of habitats (EVI BIO)

This index reflects the vulnerability to the unchainment of impacts related to the biodiversity loss and fragmentation of habitats. The information was obtained from the land cover map. It is composed by the average of the vulnerability indexes relative to the area of the fragments of savannah vegetation and seasonal forest, shapes of the fragments and distance between the fragments, which will be hereinafter described. In this way, EVI BIO (Figure 3) is described by the following function:

$$
\mathrm{EVI} \mathrm{BIO}=\frac{\text { EVI AREA }+ \text { EVI SHAPE }+ \text { EVI DIST }}{3}
$$




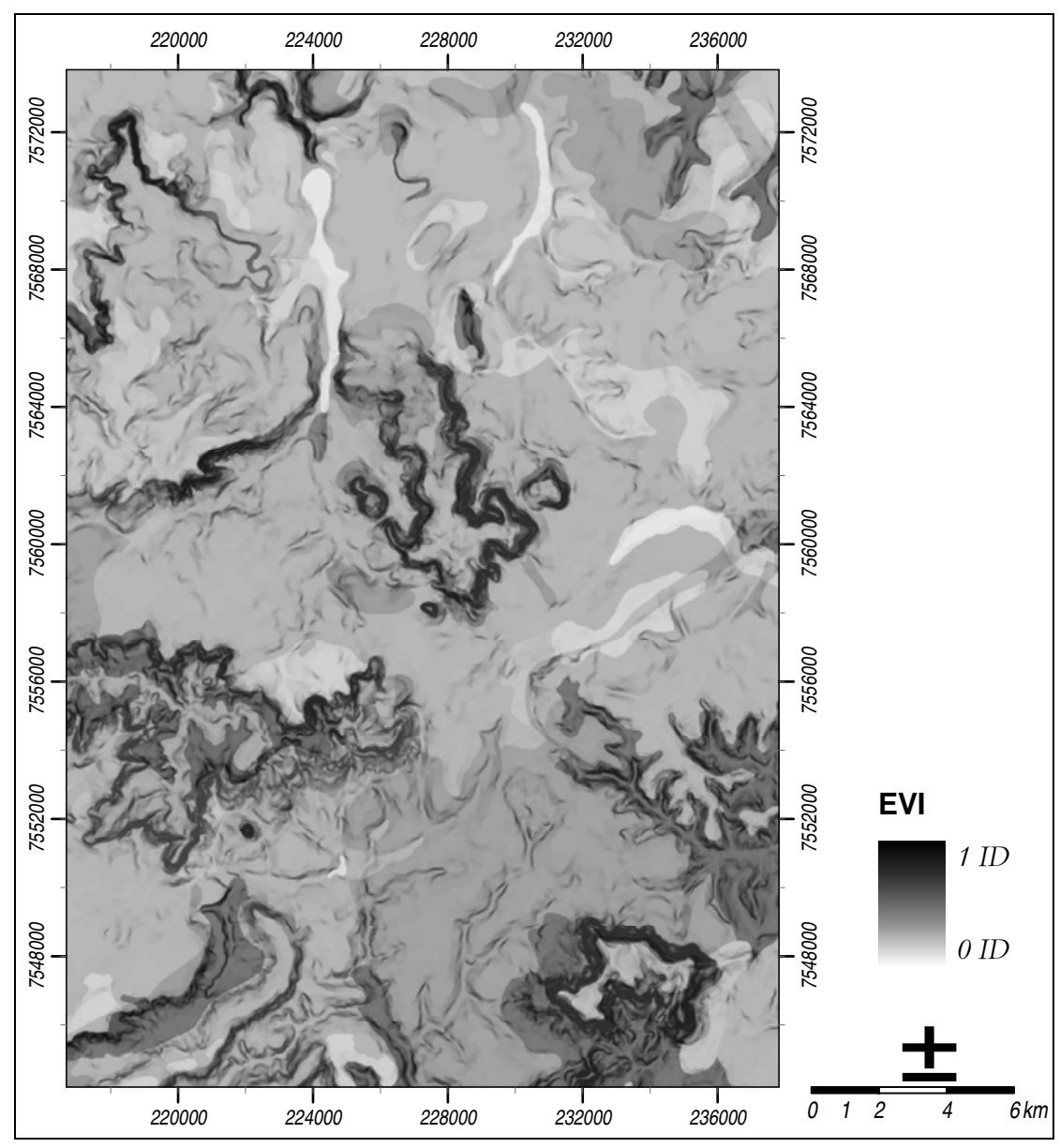

Figure 1 - Environmental Vulnerability Index (EVI) related to erosion

Table 3 - Scores for the EVI related to geology.

\begin{tabular}{llc}
\hline Geological Formation & Mineral Composition & Score \\
\hline Quaternary recent deposits & Unconsolidated sediments (sands, clay and gravel) & 3.00 \\
Santa. Rita do Passa Quatro Formation & Sand deposits & 3.00 \\
Piraçununga Formation & Unconsolidated sand sediments & 3.00 \\
Itaqueri Formation & Sandstone & 2.40 \\
Serra Geral Formation & Basalt and diabase & 1.50 \\
Botucatu Formation & Sandstone & 2.40 \\
Pirambóia Formation & Sandstone & 2.40 \\
Corumbataí Formation & Claystones and Siltstones & 2.70 \\
\hline
\end{tabular}




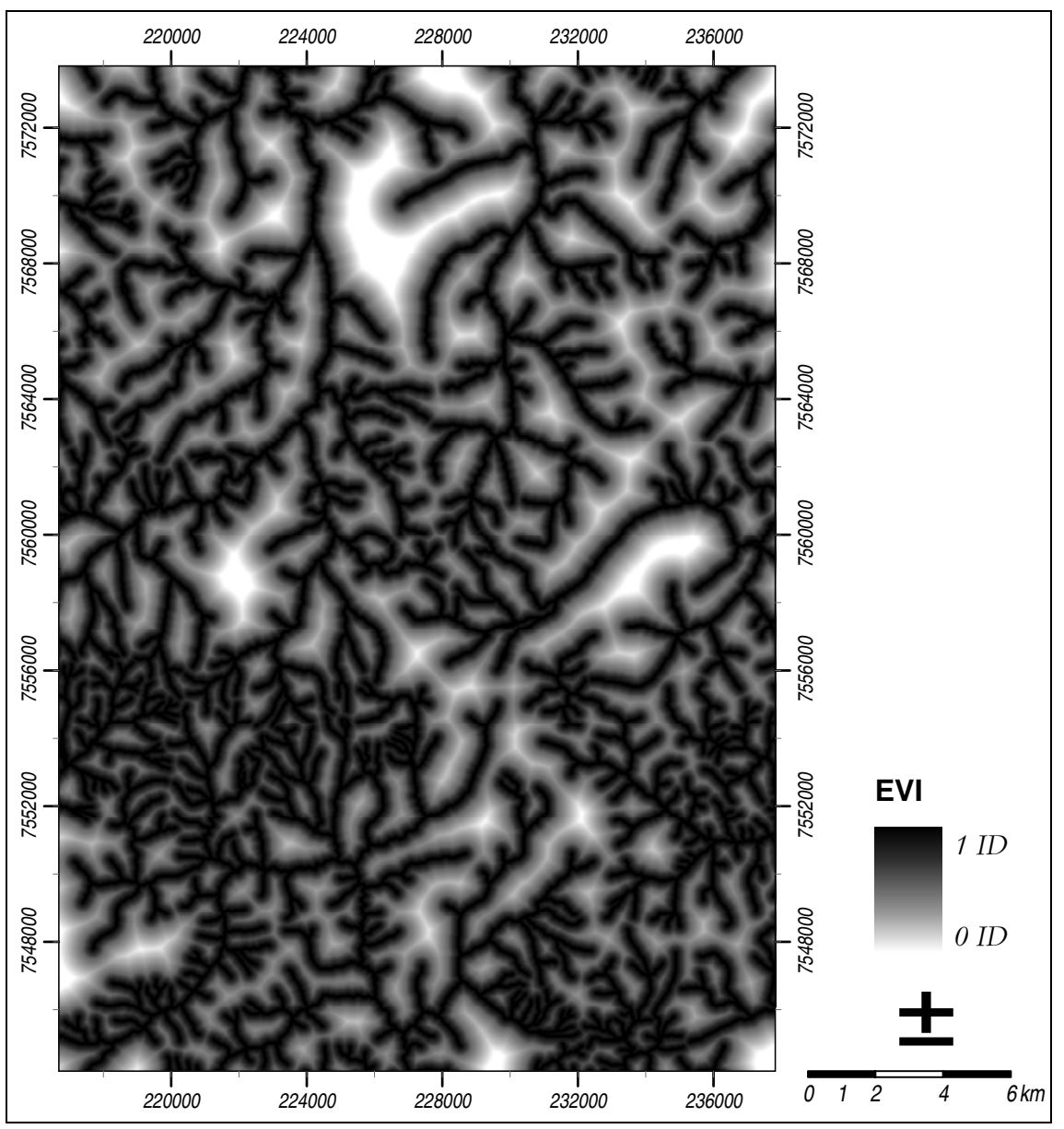

Figure 2 - Environmental Vulnerability Index (EVI) related to hydrological resources.

For the EVI related to the area of the vegetation fragments (EVI AREA) it is considered that the larger it is the area of a savannah or seasonal forest remainder, the greater it will be its environmental quality concerning biodiversity and consequently the greater it will be the vulnerability in relation to the suppression of this remainder. The smaller is the fragment, the greater the influence of the external factors on it. In small fragments, the ecosystem dynamics is probably determined by external forces and not internal ones (Saunders et al., 1991). Several studies highlight a greater intensity of the edge effects in small fragments, with increase in the mortality of trees and in the substitution taxes, modification in the recruitment taxes, besides severe microclimatic alterations exhibited in the temperature and intensity of the winds (MMA/SBF, 2003).
For the analysis of the area of the seasonal forest and savannah remainders, the map of use and occupation has been reclassified with the objective of generation of a map containing only such remainders. After the reclassification, each fragment was isolated by attributing a specific identifier for each one. Since then it was possible to calculate the area of each fragment, by generating a new raster image where each fragment is linked to its area.

For the calculation of the Vulnerability Index related to the area of the vegetation remainders, the fuzzy logic procedure was applied on the image representing the area of each fragment. It was considered as minimum impact degree $(\mathrm{EVI}=$ 0 ID) the value of 0 hectare, in other words, places where vegetation fragments don't occur. For the 
maximum impact degree $(\mathrm{EVI}=1$ ID) it was considered fragments larger than 1000 hectares.

The EVI related to the shape of the vegetation fragments (EVI SHAPE) assumes that fragments of habitats closer to the circular shape have the perimeter/area rate minimized and, therefore, the center of the area is more distant from the edges and, consequently, more protected from the external factors.

The habitat fragment shape directly affects the relation between the perimeter and the area of that fragment. The smaller this relation, the smaller the edge will also be and as larger the relation, the larger the edge will be. The area amount of a fragment represented by the edge is, therefore, direct consequence of that relation. The edge may be defined as the contact zone between a natural habitat and another anthropic one. This way, as larger the proportion of the edge of a fragment, the smaller the central area will be, which is the area effectively preserved and the most similar to the original vegetation (MMA/SBF, 2003).

For effect of the calculation of the EVI related to the shape of the vegetation remainders, the shape index proposed by Valente (2001), which expresses the shape of the fragments in function of the perimeter / area rate of the fragment, compared to a pattern shape. When the raster format is used for the maps, the pattern shape will be constituted of a square. This way, the more distant of that pattern, the more irregular its shape is considered and the fragment will be more subject to the edge effects, what can implicate in reduction of its environmental quality. The proposed shape index is expressed by the following function:

$$
\mathrm{SHAPE}=\frac{0,25 \mathrm{p}}{\sqrt{\mathrm{a}}}
$$

where,

$\mathrm{p}=$ fragment perimeter;

$\mathrm{a}=$ fragment area

The image containing the vegetation remainders was used for the calculation of each fragment perimeter and through the PERIM function of IDRISI, a new raster image was generated representing each fragment associated to its perimeter. Through the "image calculator" module, the shape index proposed by Valente (2001) was applied, resulting in a new image where each fragment presents a value related to its shape. These values vary between 1 and 12 . The closer to 1 , the lesser the edger effect will be, the greater its environmental quality will be and the greater its environmental vulnerability index will be related to the shape. This way, it was considered as minimum impact degree (EVI $=0$ ID), areas where the shape index of the fragments was greater than 12 . The maximum impact degree (EVI=1 ID) corresponds to areas where the shape index of the fragments is equal to 1 .

The EVI related to the distance between the vegetation fragments (EVI DIST) assumes that the neighbouring of the fragment, known as matrix, determines the possibility of displacement of the species between the fragments and the establishment of plants in the matrix itself. For species whose dispersion of propagules is zoochore, the limitations to the dispersion are greater than for those scattered by the wind (anemochory), because the dispersing animals propagules can be absent or in low number in the area, or even not moving through the matrix. In general, the closer amongst themselves the fragments are, the greater the probability that movements of propagules take place among them (MMA/SBF, 2003).

For the calculation of EVI related to the distance between the fragments, the DISTANCE module of SIG IDRISI was applied, by generating a new image representing the distance between the fragments. This way, it was considered with minimum impact degree (EVI $=0$ ID), areas where the distance between the fragments was greater than 1000 meters. The maximum impact degree $(\mathrm{EVI}=1$ ID) corresponds to areas where the distance between the fragments approaches zero. 


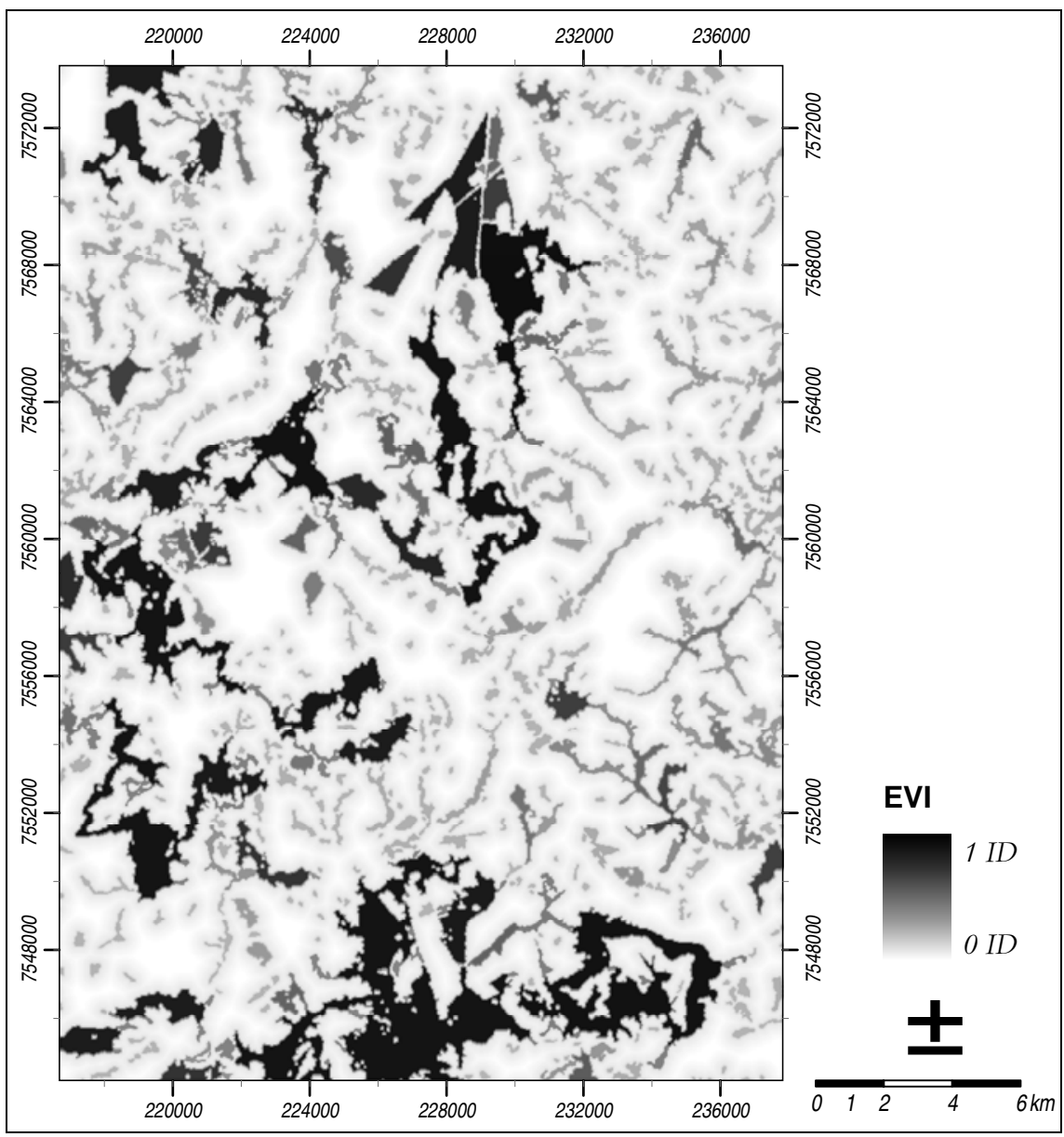

Figure 3 - Environmental Vulnerability Index (EVI) related to biodiversity loss

Final Environmental Vulnerability Index (EVI FINAL)

The Final Environmental Vulnerability Index represents the average of the considered intermediate indexes, expressed by the following function:

EVI FINAL $=\frac{\text { EVI EROSION }+ \text { EVI HYDRO }+ \text { EVI BIO }}{3}$

This function was applied in IDRISI, through the "image calculator" module, by generating a new image representing EVI FINAL (Figure 5).

\section{Determination of the environmental compensation percentage value \\ Through geoprocessing, the polygon of the enterprise area in the final map of environmental vulnerability was digitized, by calculating the average of the values contained in the polygon.}

This was converted in a new quantitative scale, representing the percentage of the costs relative to the enterprise implantation that was applied as compensation in the Conservation Units, as the legal rules determine. A compensation scale was adopted in accordance with what has been practiced now by the federal licensing environmental authority, i.e., the minimum of $0.50 \%$ and the maximum of $5.00 \%$ the total cost (see Figure 4). Because it is a dynamic methodology, such values can be adapted according to the local reality, since obeying what it is determined in the effective legal instruments.

For illustrative effects, five areas in a random way were selected in the study area. The results are in Table 4 and Figure 5 shows the Final Map of Environmental Vulnerability Indexes. 


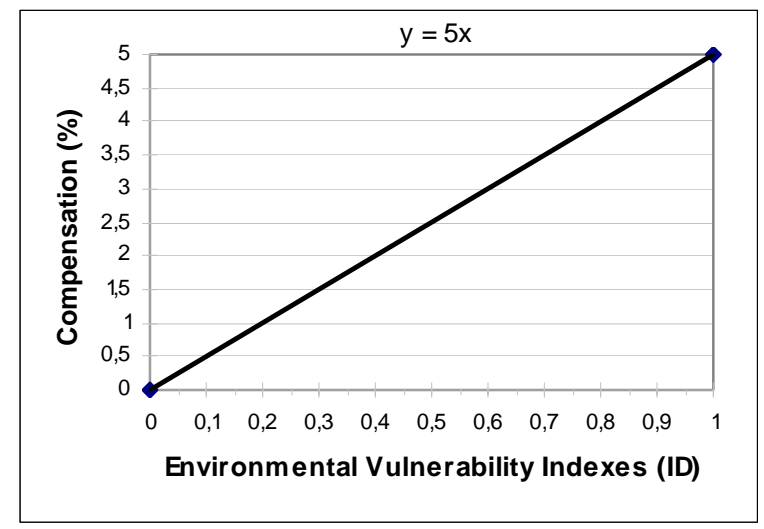

Figure 4 - Conversion from EVI into compensation percentage value

Table 4 - Example of the conversion of environmental vulnerability indexes into compensation percentage value

\begin{tabular}{ccc}
\hline Enterprise & EVI Final (ID) & Compensation Value (\%) \\
\hline A & 0.389591 & 1.95 \\
B & 0.662436 & 3.31 \\
C & 0.765183 & 3.83 \\
D & 0.664791 & 3.32 \\
E & 0.291692 & 1.46 \\
\hline
\end{tabular}

\section{CONCLUSIONS}

The present methodological proposal represented an important instrument of environmental and economical planning, since it allowed analyzing local alternatives of certain enterprise with the objective of reducing the impacts and at the same time reducing the costs of environmental compensation defined by the article 36 of Law $9.985 / 2000$. The application of the methodology significantly reduced the subjectivity degree usually associated with most part of the methodologies of impact evaluation. However, this reduction was not total, because some subjectivity degree could take place in the attribution of the values of minimum and maximum impact degree associated to the several Indexes of Environmental Vulnerability.

The progress of the scientific knowledge about the environmental characteristics of the area to be evaluated, as well as of the knowledge about the interaction between the environmental components and the resulting impacts of several activities and enterprises could result further reduction of the subjectivity degree in the determination of the environmental vulnerability indexes and in the analysis of the impact degree.

The methodology could be adapted to several kinds of enterprises, by aggregating new environmental vulnerability indexes according to the availability of the information and local reality. 


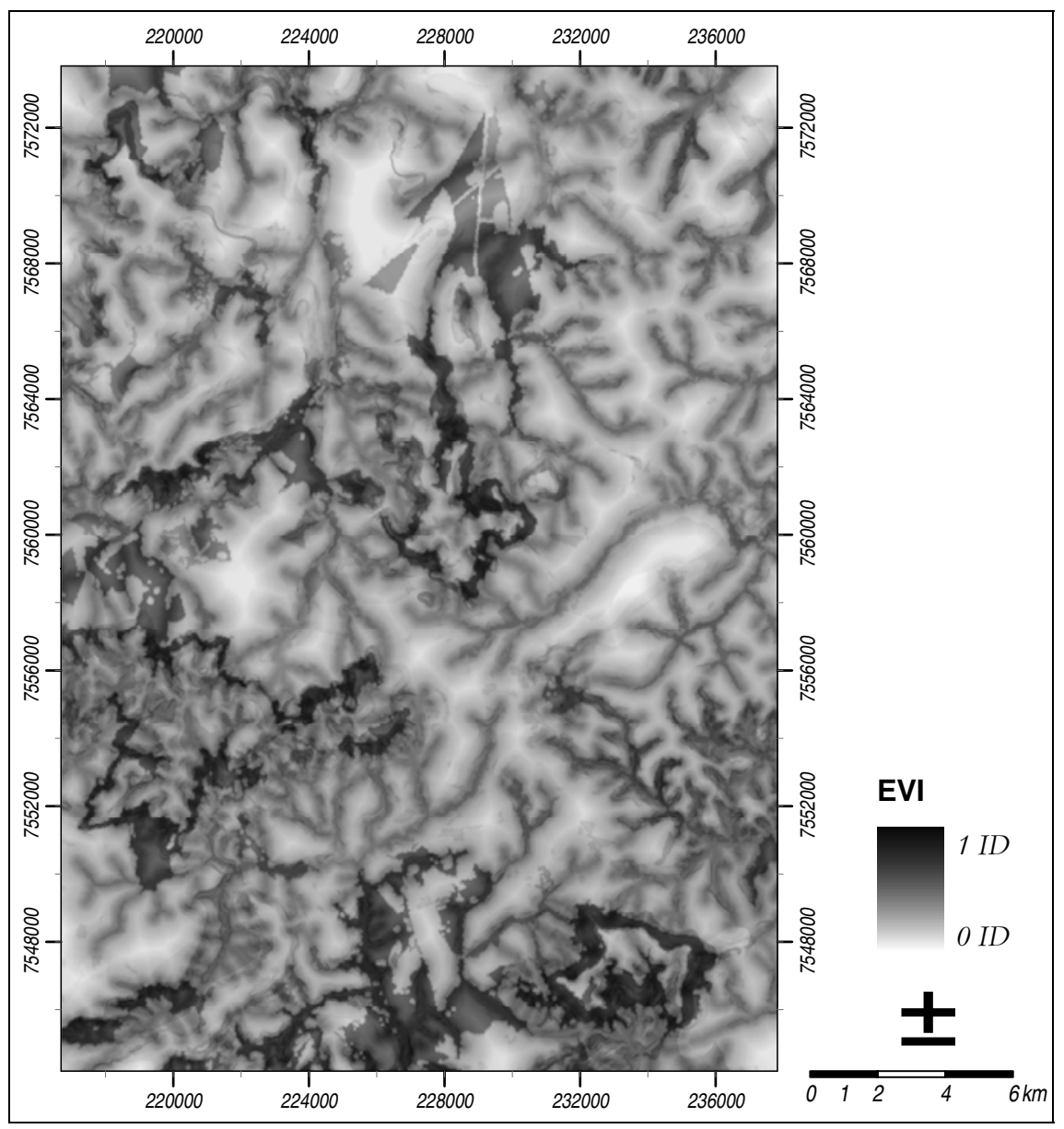

Figure 5 - Final Map of Environmental Vulnerability Indexes

\section{RESUMO}

O termo compensação ambiental refere-se à obrigação do empreendedor em apoiar a implantação e manutenção de Unidades de Conservação, aplicável a empreendimentos de significativo impacto ambiental, de acordo com a Lei 9.986/2000. Esta lei estabelece que o volume de recursos a ser aplicado pelo empreendedor deve ser de no mínimo $0,5 \%$ dos custos totais previstos para a implantação do empreendimento, sendo que este percentual deve ser fixado pelo órgão ambiental competente, de acordo com o grau de impacto ambiental. Sendo assim, o presente artigo tem o objetivo de propor uma metodologia para quantificação da compensação ambiental através da análise espacial de indicadores de vulnerabilidade ambiental. A proposta foi aplicada através de um estudo de caso em empreendimentos de mineração de areia, na região de
Descalvado/Analândia, interior do Estado de São Paulo. Índices de vulnerabilidade ambiental foram atribuídos a indicadores de impactos relacionados à erosão, recursos hídricos e perda de biodiversidade. Esta metodologia representa importante instrumento de planejamento ambiental e econômico, podendo ser adaptada a diversos tipos de empreendimentos e realidades locais, contribuindo para a redução do grau de subjetividade geralmente associado ao processo de avaliação de impacto ambiental.

\section{REFERENCES}

Antunes P, Santos R, Jordão, L, Goncalves P, Videira N. (1996), A GIS-based decision support system for Environmental Impact Assessment. Proc IAIA'96 Conf, Estoril, Portugal, pp. 451-6. 
Antunes, P.; Santos, R.; \& Jordão, L. (2001), The application of Geographical Inrformation Systems to determine environmental impact significance. Environmental Impact Assessment Review. 21: 511 535.

Brasil-Instituto Brasileiro de Geografia e Estatística. (1971a), Descalvado. Carta do Brasil - Escala 1:50000. Folha SF-23-V-C-IV-4. $1^{\text {a }}$ edição. Fundação IBGE. Departamento de Cartografia.

Brasil- Instituto Brasileiro de Geografia e Estatística. (1971b). Corumbataí. Carta do Brasil - Escala 1:50000. Folha SF-23-Y-A-I-2. 1 a edição. Fundação IBGE. Departamento de Cartografia.

Cowell, R. (2003), Substitution and scalar politics: negotiating environmental compensation in Cardiff Bay. Geoforum 34: 343-358.

Crepani, E.; Medeiros, J.S.; Azevedo, L.G.; Hernandez Filho, P.; Florenzano, T.G. \& Duarte, V. (1998), Curso de sensoriamento remoto aplicado ao zoneamento ecológico-econômico. São José dos Campos: INPE.

Cuperus, R.; Bakermans, M.M.G.J.; De Haes, H.A.U. \& Canters, K.J. (2001) Ecological compensation in Dutch Highway Planning. Environmental Management. Vol.27, no. 1, pp. 75-89.

Dias, E.G.C da S. (2001), Avaliação de impacto ambiental de projetos de mineração no Estado de São Paulo: a etapa de acompanhamento. Escola Politécnica da Universidade de São Paulo. Departamento de Engenharia de Minas. Tese (Doutorado). 283p.

Eastman, J.R. (1997). Idrisi for Windows. Tutorial Exercises. Version 2.0. Clark Labs for Cartographic Technology and Geographic Analysis. Clark University.

Ministério do Meio Ambiente/Secretaria de Biodiversidade e Florestas. (2003), Fragmentação de Ecossistemas: Causas, efeitos sobre a biodiversidade e recomendações de políticas públicas/ Denise Marçal Rambaldi, Daniela América Suárez de Oliveira (orgs.). Brasília: MMA/SBF. 510p.
OLIVEIRA,J.B.; PRADO,H. \& ALMEIDA,C.L.F. (1982), Carta pedológica semi-detalhada do Estado de São Paulo: Quadrícula de Descalvado. Escala 1:100.000. 1a Edição. 1 mapa. Instituto Agronômico. Campinas. Seção de Pedologia..

OLIVEIRA,J.B.; PRADO,H. \& ALMEIDA,C.L.F. (1981), Carta pedológica semi-detalhada do Estado de São Paulo: Quadrícula de São Carlos. Escala 1:100.000. 1a Edição. 1 mapa. Instituto Agronômico. Campinas. Seção de Pedologia.

São Paulo. Secretaria de Agricultura e Abastecimento. Coordenadoria da Pesquisa de Recursos Naturais. Instituto Geológico. (1984), Formações geológicas de superfície - Folha geológica de Descalvado, Folha SF.23-V-C-IV-4 Escala 1:50.000. Rio de Janeiro: Aerofoto Cruzeiro.

São Paulo. Secretaria de Agricultura e Abastecimento. Coordenadoria da Pesquisa de Recursos Naturais. Instituto Geológico. (1984-b), Formações geológicas de superfície - Folha geológica de Corumbataí, Folha SF.23-Y-A-1-2. Escala 1:50.000. Rio de Janeiro: Aerofoto Cruzeiro.

Saunders, D.A.; Hobbs, R.J. \& Margules, C.R. (1991). Biological consequences of ecosystem fragmentation: a review. Conservation Biology, 7: 18-32.

Souza, C.J. da S. de. (1998), Carta de vulnerabilidade à erosão como subsídio ao zoneamento ecológicoeconômico em área intensamente antropizada. São José dos Campos: INPE.. 172p. Dissertação (mestrado).

Valente, R. de O.A. (2001), Análise da estrutura da paisagem na bacia do rio Corumbataí, $\mathbf{S P}$. Dissertação (mestrado). USP/ESALQ. Piracicaba, SP. $144 p$.

Received: January 26, 2005; Revised: March 07, 2006; Accepted: May 13, 2008. 